\title{
Purification and properties of arylmannosidases from mung bean seedlings and soybean cells
}

Irena Pastuszak, G.P. Kaushal, K.A. Wall, Y.T. Pan, A. Sturm $^{2}$ and A.D. Elbein ${ }^{1}$

Department of Biochemistry, Unıversity of Texas Health Science Center, San Antonio, TX 78284, USA and ${ }^{2}$ Friedrich Miescher Institute, Basel, Switzerland

${ }^{1}$ To whom correspondence should be addressed

Two arylmannosidases (signified as $\mathbf{A}$ and $B$ ) were purified to homogeneity from soluble and microsomal fractions of mung bean seedlings. Arylmannosidase A from the microsomes appeared the same on native gels and on SDS gels as soluble arylmannosidase $\mathbf{A}$, the same was true for arylmannosidase $\mathbf{B}$. Sedimentation velocity studies indicated that both enzymes were homogeneous, and that arylmannosidase $A$ had a molecular mass of $237 \mathrm{kd}$ while $\mathrm{B}$ had a molecular mass of 243 kd. Arylmannosidase A showed two major protein bands on SDS gels with molecular masses of 60 and $55 \mathrm{kd}$, and minor bands of 79, 39 and $35 \mathrm{kd}$. All of these bands were $\mathrm{N}$-linked since they were susceptible to digestion by endoglucosaminidase $H$. In addition, at least the major bands could be detected by Western blots with antibody raised against the xylose moiety of $\mathrm{N}$-linked plant oligosaccharides, and they could also be labeled in soybean suspension cells with $\left[2-{ }^{3} \mathrm{H}\right]$ mannose. Arylmannosidase B showed three major bands with molecular masses of 72,55 and $45 \mathrm{kd}$, and minor bands of 42 and $39 \mathrm{kd}$. With the possible exception of the 45 and $42 \mathrm{kd}$ bands, all of these bands are glycoproteins. Arylmannosidases $A$ and B showed somewhat different kinetics in terms of mannose release from high-mannose oligosaccharides, but they were equally susceptible to inhibition by swainsonine and mannostatin A. Polyclonal antibody raised against the arylmannosidase $B$ cross-reacted equally well with arylmannosidase $A$ from mung bean seedlings and with arylmannosidase from soybean cells. However, monoclonal antibody against mung bean arylmannosidase $A$ was much less effective against arylmannosidase B. Antibody was used to examine the biosynthesis and structure of the carbohydrate chains of arylmannosidase in soybean cells grown in $\left[2-{ }^{3} \mathrm{H}\right]$ mannose. Treatment of the purified enzyme with Endo $\mathrm{H}$ released $\sim 50 \%$ of the radioactivity, and these labeled oligosaccharides were of the high-mannose type, i.e. mostly $\operatorname{Man}_{9}$ GlcNAc. The precipitated protein isolated from the Endo $\mathrm{H}$ treatment still contained $50 \%$ of the radioactivity, and this was present in modified structures that probably contain xylose residues.

Key words: Mung beans/ $\alpha$ mannosidases/glycoproteins/soybean- $\alpha$-mannosidases/xylose-containing $\mathrm{N}$-linked glycoproteins

\section{Introduction}

During the course of purification of the glycoprotein processing mannosidase II from mung bean seedlings
(Kaushal et al., 1990), we detected two other peaks of $\alpha$ mannosidase activity on DEAE-cellulose columns that also reacted with the $p$-nitrophenyl- $\alpha$-D-mannopyranoside substrate. In order to determine the relationship of these activities to mannosidase II and to the processing of $\mathrm{N}$ linked oligosaccharides in general, we decided to purify these enzymes to homogeneity so that we could determine their structures and properties. Plant cells, like animal cells, have two different classes of $\alpha$-mannosidases which differ in their $\mathrm{pH}$ optima and in their substrate specificities (Forsee, 1985; Szumilo et al., 1986a). One class is the glycoprotein processing $\alpha$-mannosidases, mannosidase I (Szumilo et al., 1986a) and mannosidase II (Kaushal et al., 1990), that are involved in trimming mannose residues from high-mannose oligosaccharides of the N-linked glycoproteins (Kornfeld and Kornfeld, 1985). These enzymes have pH optima of $\sim 6.5$, reside in the endoplasmic reticulum or Golgi apparatus and act on $\mathrm{Man}_{9}(\mathrm{GlcNAc})_{2}$-proteins, or GlcNAc$\operatorname{Man}_{5}\left(\mathrm{GlcNAc}_{2}\right.$-proteins (Tulsiani et al., 1982a). Mannosidase II will also utilize $p$-nitrophenyl- $\alpha$-D-mannopyranoside as a substrate, while mannosidase $\mathrm{I}$ is inactive on this substrate (Kaushal et al., 1990). These various enzymes can also be distinguished by their susceptibility to various glycosidase inhibitors (Elbein, 1988).

The second class of mannosidases comprises the aryl- $\alpha$ mannosidases that have $\mathrm{pH}$ optima of $\sim 3.5-5.0$, show rather broad aglycone specificities, including $p$-nitrophenyl$\alpha$-mannopyranoside, and are usually associated with vacuoles or protein bodies of plants (McGee and Murray, 1985) or lysosomes of animals (Opheim and Touster, 1978). These enzymes are probably involved in catabolism and turnover of N-linked glycoproteins (Neely and Beevers, 1980). Arylmannosidases that are associated with the plant cell wall (Greve and Ordin, 1977; Van der Wilden and Chrispeels, 1983) have also been described. Since the cell wall is considered to be involved in lytic activity, a similar glycoprotein degradative function could be postulated for cell wall mannosidases (Greve and Ordin, 1977).

In this report we have purified 2 aryl- $\alpha$-mannosidases from the microsomal and soluble fractions of mung bean seedlings. Polyclonal antibodies prepared against either of these enzymes cross-reacts with the other protein, as well as with arylmannosidase activity isolated from the soluble fraction of mung bean seedlings. The antibodies also crossreact with proteins from suspension cultured soybean cells. A monoclonal antibody raised against one of the mung bean enzymes, however, only reacts with that native enzyme and reacts poorly with the other native mannosidase. Various properties of the two aryl- $\alpha$-mannosidases are presented in order to compare them to each other and to the known processing mannosidases. Having determined the various properties of these two arylmannosidases, it seems likely that they are protein body or vacuolar enzymes, and are solubilized by disruption of these organelles during cell 
breakage. The small amount of enzyme found associated with the microsomal pellet is probably due to enzymes that are in the process of being synthesized or trimmed in the endoplasmic reticulum or Golgi apparatus.

\section{Results}

\section{Purification of aryl- $\alpha-$ mannosidases}

Two different aryl- $\alpha$-mannosidases (i.e. enzymes that use $p$ nitrophenyl- $\alpha$-D-mannopyranoside as substrate) were separated from each other by chromatography of the mung bean extract on DEAE - cellulose (see below), and each of these enzymes was purified to homogeneity by the procedures described below. Although much of the purification shown here was done with the microsomal fraction, later studies showed that these enzymes were also in the cytoplasmic fraction, and their purification could be performed with the same methodology.

Ammonium sulfate precipitation. Solid ammonium sulfate was added slowly with stirring to 51 of supernatant liquid from the solubilization step to bring the mixture to $75 \%$ saturation of ammonium sulfate. The mixture was allowed to stand for $30 \mathrm{~min}$ in ice and the precipitate was isolated by centrifugation at $7000 \mathrm{~g}$ for $30 \mathrm{~min}$. The supernatant liquid was discarded and the pellet was dissolved in $\sim 400 \mathrm{ml}$ of 10 mM HEPES buffer, $\mathrm{pH} 7.2$, containing $5 \%$ glycerol, and dialyzed against the same buffer.

$D E A E$-cellulose chromatography. The dialysate from the ammonium sulfate precipitation $(400 \mathrm{ml})$ was applied to a $3.7 \times 42 \mathrm{~cm}$ column of DE-52 that had been equilibrated with $10 \mathrm{mM}$ HEPES buffer, $\mathrm{pH}$ 7.2. The column was washed well with the equilibration buffer and was then eluted with a $0-300 \mathrm{mM}$ gradient elution of $\mathrm{NaCl}$ in the same buffer. The elution profiles of several different glycosidases that are present in the mung bean extract are shown in Figure 1. Two different peaks of arylmannosidase activity emerged earliest from this column (at $\sim 50-100 \mathrm{mM}$ salt), followed by the peak of mannosidase II activity $(\sim 150 \mathrm{mM}$ salt) and then a peak of glucosidase II activity $(\sim 250 \mathrm{mM}$ salt). Since the two peaks of arylmannosidase activity were not well separated and in some cases emerged as a shoulder and a main peak, we pooled the two peaks together (e.g. fractions $150-190$ on this column) and separated them at the next purification step (i.e. phosphocellulose).

Chromatography on phosphocellulose. The pooled arylmannosidase peak from DEAE-cellulose was dialyzed overnight against $10 \mathrm{mM}$ acetate buffer, $\mathrm{pH}$ 5.2. It was then applied to a $1.9 \times 10 \mathrm{~cm}$ column of cellulose phosphate that was prepared and equilibrated in acetate buffer, $\mathrm{pH}$ 5.2. The column was washed well with buffer and then eluted with a linear gradient of $0-200 \mathrm{mM} \mathrm{NaCl}$ in the same buffer. As shown in Figure 2, this gradient separated the two peaks of aryl- $\alpha$-mannosidase activity. The first peak, which was labeled arylmannosidase A, emerged at $\sim 50-75 \mathrm{mM} \mathrm{NaCl}$, while the second peak, labeled arylmannosidase B, emerged at $\sim 100-150 \mathrm{mM} \mathrm{NaCl}$. These two peaks were pooled individually and each was purified to homogeneity as described below.

Hydroxyapatite chromatography. The pooled fractions from the phosphocellulose column (either peak A or peak B) were dialyzed overnight against $10 \mathrm{mM}$ phosphate buffer, $\mathrm{pH}$ 7.1. The dialyzed preparations were applied to a $1.6 \times$ $8.5 \mathrm{~cm}$ column of hydroxyapatite that had been equilibrated with $10 \mathrm{mM}$ phosphate buffer, $\mathrm{pH}$ 7.1. The column was washed well with the equilibration buffer and was then eluted with a linear gradient of 10-250 mM phosphate buffer, $\mathrm{pH}$ 7.1. Arylmannosidase A activity emerged from the column at $50-120 \mathrm{mM}$ phosphate buffer whereas arylmannosidase B emerged at $80-200 \mathrm{mM}$ phosphate buffer (data not shown).

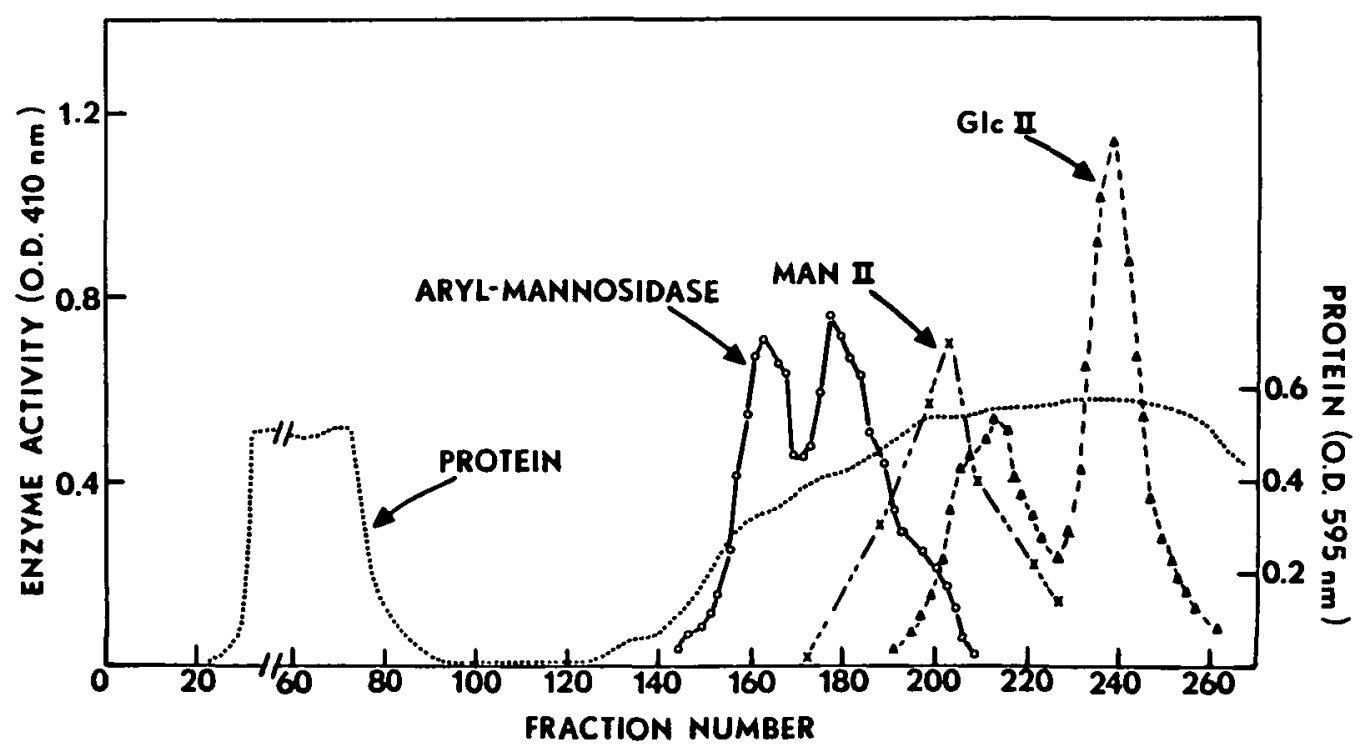

Fig. 1. Purification of arylmannosidases by DEAE-cellulose chromatography. The solubilized (or cytosolic) enzyme fraction prepared from mung bean microsomes was applied to a DE-52 column that had been equilibrated with $10 \mathrm{mM}$ HEPES buffer containing $10 \%$ glycerol and $0.1 \%$ Triton $\mathrm{X}-100$. The column $(3.7 \times 45 \mathrm{~cm})$ was washed with Tris buffer and eluted with $800 \mathrm{ml}$ of a linear gradient of $0-03 \mathrm{M} \mathrm{NaCl}$ in the same buffer. Two peaks of arylmannosidase activity emerged from this column at $\sim 50-100 \mathrm{mM}$ salt, followed by a peak of mannosidase II ( $\sim 150 \mathrm{mM}$ salt) and then a peak of glucosidase II ( $\sim 250 \mathrm{mM}$ salt). Active fractions were pooled for the next purification step. 
Purification using Concanavalin A-Sepharose. The active fractions from the hydroxyapatite column were pooled, concentrated to $\sim 10 \mathrm{ml}$ on the Amicon filtration apparatus and then mixed with $2 \mathrm{ml}$ of a suspension of Concanavalin A-Sepharose $(15 \mathrm{mg} / \mathrm{ml})$. The mixture was allowed to stand at $0^{\circ} \mathrm{C}$ for $3 \mathrm{~h}$ with occasional stirring and was then transferred to a small glass column. The column was washed

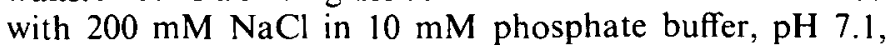

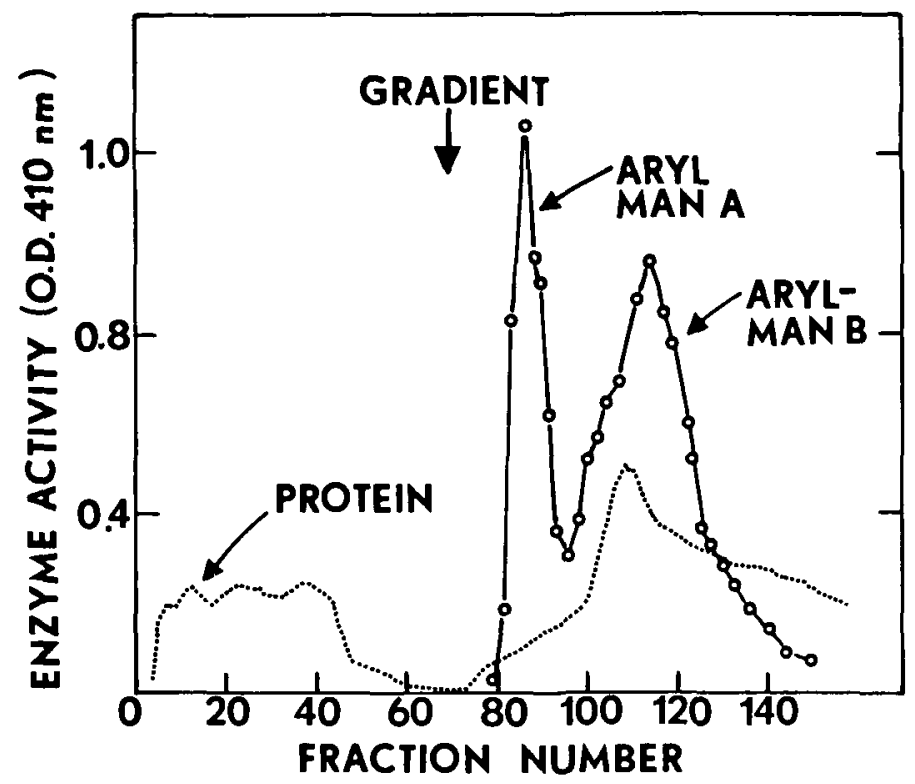

Fig. 2. Separation of arylmannosidase A from arylmannosidase B by cellulose phosphate chromatography. The column was prepared and equilibrated as described in the text. The bound enzymes were eluted with a $0-0.2 \mathrm{M}$ linear gradient of $\mathrm{NaCl}$. Fractions of $4 \mathrm{ml}$ were collected and assayed for aylmannosidase activity as described in the text. Active fractions were pooled for the next purification step. also containing $1 \mathrm{mM} \mathrm{CaCl}_{2}$ and $1 \mathrm{mM} \mathrm{MgCl}$. Then $0.3 \mathrm{M}$ $\alpha$-methylmannoside was applied to the columns, and the columns were stoppered and stored in the cold for $\sim 5 \mathrm{~h}$ while in contact with the eluent. The elution was then continued with additional amounts of $\alpha$-methylmannoside being passed through the column. Fractions were collected and those fractions showing $\alpha$-mannosidase activity were pooled and dialyzed overnight against $10 \mathrm{mM}$ HEPES buffer, $\mathrm{pH} 7.1$.

Chromatography on columns of Sephacryl S-300. The dialyzed eluate from the Concanavalin A-Sepharose was concentrated on an Amicon filter and the concentrated fraction was applied to a $1.5 \times 150 \mathrm{~cm}$ column of Sephacryl S-300 that had been equilibrated in $10 \mathrm{mM}$ HEPES buffer, $\mathrm{pH}$ 7.1. As shown in Figure 3, the enzymatic activity was eluted in a sharp, symmetrical peak with this same buffer.

Purification by polyacrylamide gel electrophoresis. Preparative non-denaturing polyacrylamide gel electrophoresis was done at $4^{\circ} \mathrm{C}$ in $7 \%$ acrylamide, $\mathrm{pH} 6.8$, as described (Orr et al., 1972). A $0.2 \mathrm{ml}$ sample (100 $\mu$ g protein) was applied to each of 18 tube gels, and electrophoresis was carried out at a current of $2 \mathrm{~mA} /$ tube. The active band was localized by incubating one of the gels in the presence of $2 \mathrm{mM} 4$ methylumbelliferyl- $\alpha$-mannoside in $50 \mathrm{mM}$ acetate buffer,

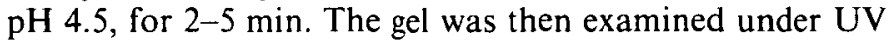
light to localize the enzyme activity. The corresponding area was sliced from the remaining gels and eluted into $10 \mathrm{mM}$ HEPES buffer, pH 7.1.

Using the above procedures, both the aryl- $\alpha$-mannosidase $A$ and aryl- $\alpha$-mannosidase $B$ were purified $\sim 1000$-fold, with a recovery of $\sim 4 \%$. These data are summarized in Table I for each step of the purification procedure. In this table the purification of the arylmannosidases found in the

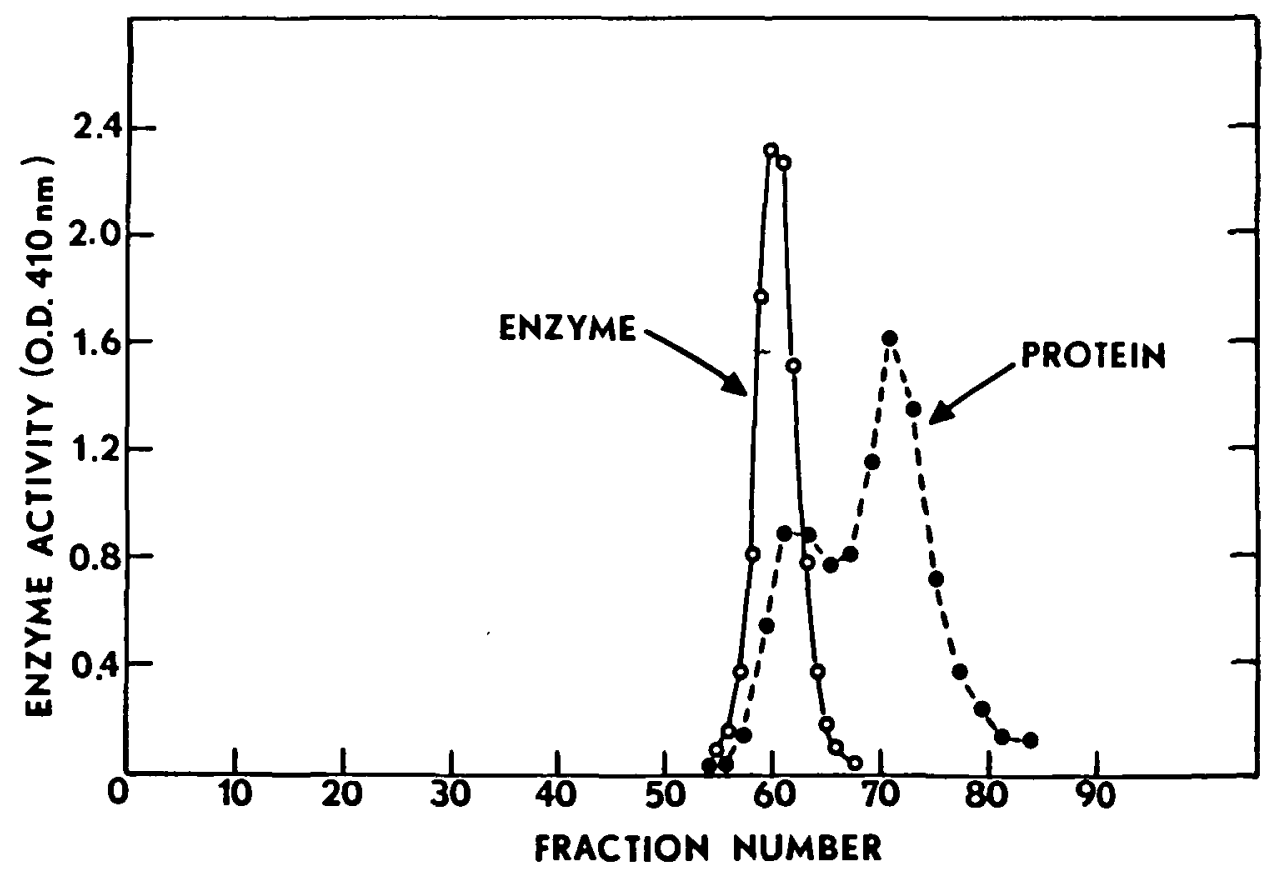

Fig. 3. Purification of arylmannosidase B on a Sephacryl S-300 column. The enzyme preparation obtained from the Concanavalin A-Sepharose column was applied to the Sephacryl S-300 column. The column was run at a flow rate of $15 \mathrm{ml} / \mathrm{h}$ and fractions of $2 \mathrm{ml}$ were collected. Each fraction was examined for enzyme activity and for the amount of protein. Fractions containing arylmannosidase activity were pooled and purified further, as described in the text. 
Table I. Purification procedure for cytoplasmic arylmannosidases (A and B)

\begin{tabular}{|c|c|c|c|c|c|c|}
\hline & \multirow[b]{2}{*}{$\begin{array}{l}\text { Step } \\
\text { (mg) }\end{array}$} & \multirow[b]{2}{*}{ Protein } & \multicolumn{2}{|c|}{ Activity } & \multirow[b]{2}{*}{ Purification } & \multirow[b]{2}{*}{ Yield } \\
\hline & & & $\begin{array}{l}\text { Total } \\
\text { (fold) }\end{array}$ & $\begin{array}{l}\text { Sp. act } \\
(\%)\end{array}$ & & \\
\hline 1. & Supernatant & 12000 & 284.5 & 0.024 & & 100 \\
\hline 2. & $\begin{array}{l}\text { Ammonium sulfate } \\
\text { precipitation }\end{array}$ & 10000 & 275.8 & 0.027 & 1.12 & 96.9 \\
\hline 3 & DE-52 & 1560 & 269. & 0.172 & 7.16 & 94.5 \\
\hline \multirow[t]{3}{*}{4.} & Cellulose phosphate & & & & & \\
\hline & A & 40 & 114.8 & 2.87 & 119.58 & 40.3 \\
\hline & B & 90 & 122 & 1.35 & 56.25 & 42.9 \\
\hline \multirow[t]{3}{*}{5.} & HAP & & & & & \\
\hline & arylman. A & 10.5 & 84.9 & 8.086 & 336.92 & 298 \\
\hline & arylman. B & 17. & 61.8 & 3.635 & 151.45 & 217 \\
\hline \multirow[t]{3}{*}{6.} & Con A & & & & & \\
\hline & arylman. A & 3.1 & 45.9 & 14.8 & 616.66 & 161 \\
\hline & arylman. B & 5. & 43.9 & 8.78 & 365.83 & 15.4 \\
\hline \multirow[t]{3}{*}{7.} & Sephacryl S-300 & & & & & \\
\hline & A & 21 & 41.3 & 19.7 & 82083 & 14.5 \\
\hline & B & 2.4 & 33.4 & 1392 & 580.0 & 117 \\
\hline \multirow[t]{3}{*}{8.} & $\begin{array}{l}\text { Polyacrylamide gel } \\
\text { electrophoresis }\end{array}$ & & & & & \\
\hline & A & 0.49 & 13.36 & 27.26 & 1135.8 & 4.7 \\
\hline & B & 0.44 & 11.8 & 26.8 & 1116.6 & 4.1 \\
\hline
\end{tabular}

soluble fraction rather than in the microsomal fraction is presented, since much more of the enzymes were found in soluble form. However, the purification data and properties were similar for both soluble and microsomal forms. In fact, it seems likely that these mannosidases are actually protein body enzymes that are released upon cell breakage, and the microsomal fraction may represent mannosidases in the process of being synthesized and trimmed in the endoplasmic reticulum and Golgi apparatus of the cell.

The purity of each of the arylmannosidases (both soluble and microsomal) was assessed by native gel electrophoresis and by sedimentation velocity studies. Figure 4 shows that both arylmannosidase $\mathbf{A}$ and arylmannosidase $\mathbf{B}$ gave single bands when subjected to native gel electrophoresis and staining with Coomassie Blue, and a mixture of the two enzymes gave the expected two bands. In addition, when the enzymes were examined by sedimentation equilibrium in a Model E ultracentrifuge, a straight line relationship was observed for each enzyme, indicating that each was homogeneous. The molecular mass of aryl- $\alpha$-mannosidase $A$ was estimated to be 237000 and that of aryl- $\alpha$-mannosidase $B$ to be 243000 . It is unlikely that arylmannosidase $A$ could be a proteolytic product of arylmannosidase $B$ since the two enzymes are still isolated in about the same ratios when various protease inhibitors are included in the purification buffers (e.g. leupeptin, pepstatin, PMSF and aprotinin). In addition, one would not expect a single product after protease treatment, as is seen in Figure 4.

The two mannosidases were also examined by SDS gel electrophoresis to compare their subunit composition, as shown in Figure 5. In this case, the two enzymes appear to be somewhat different, although they apparently do have some subunits in common. Thus, as seen in lane A, aryl- $\alpha-$ mannosidase A shows two major subunits, with mol.wts of $\sim 59.5$ and $55.5 \mathrm{kd}$. There were also smaller amounts of four or five other protein bands, which had mol.wts of 72, $39,35,32$ and $24 \mathrm{kd}$. It is not clear whether these other bands are the result of proteolysis, whether they come from contamination of the A enzyme by the B enzyme or whether they are integral parts of the enzyme. Lane B in Figure 5 shows that each of these subunits is a glycoprotein and contains a high-mannose (or hybrid) type of N-linked oligosaccharide, since the mobility of each band was increased by digestion with endoglucosaminidase $H$. This increase in migration rate suggests the loss of $\sim 2 \mathrm{kd}$, which would indicate the removal of one oligosaccharide chain.

In order to determine whether arylmannosidases have complex or modified oligosaccharides in addition to the high-mannose chains, arylmannosidase $A$ was treated with trifluoromethanesulfonic acid (TFMS) to remove all of the carbohydrate, and the protein was run on gels as shown in Figure $5 \mathrm{~b}$. Lane 2 shows the migration of the original subunits of arylmannosidase $A$ whereas lane 3 is after treatment with endo $H$, and lane 4 after TFMS treatment. It can be seen that removal of all the carbohydrate resulted in faster moving protein bands, indicating that each subunit contained at least one modified oligosaccharide in addition to the high-mannose structure. Further evidence for this is seen in Figure 12.

When aryl- $\alpha$-mannosidase $B$ was subjected to SDS gel electrophoresis it gave three major bands, with estimated mol.wts of $72,55.5$ and $45.4 \mathrm{kd}$, and minor bands of 42.5 and $39 \mathrm{kd}$. In this case, the $72,55.5$ and $39 \mathrm{kd}$ subunits were $\mathrm{N}$-linked glycoproteins, as shown by their increased mobility after digestion with endoglucosaminidase $H$, but the 45.5 and $42.5 \mathrm{kd}$ bands were resistant to Endo $\mathrm{H}$, indicating that they do not contain high-mannose or hybrid types of oligosaccharides. They could, of course, still be N-linked glycoproteins with Endo $\mathrm{H}$-resistant chains. At this stage, the relationship of arylmannosidase $A$ to arylmannosidase $B$ is not clear, nor is the origin of each of the protein bands seen in this figure.

The purified enzymes were quite stable, either stored in an ice bucket or frozen at $-20^{\circ} \mathrm{C}$, as long as the storage buffer contained $10 \%$ glycerol and $0.5 \mathrm{mM}$ dithiothreitol. Thus, the enzymes have been kept in the frozen state for several months with no detectable loss of activity. However, when either enzyme was stored in the cold for a week in 


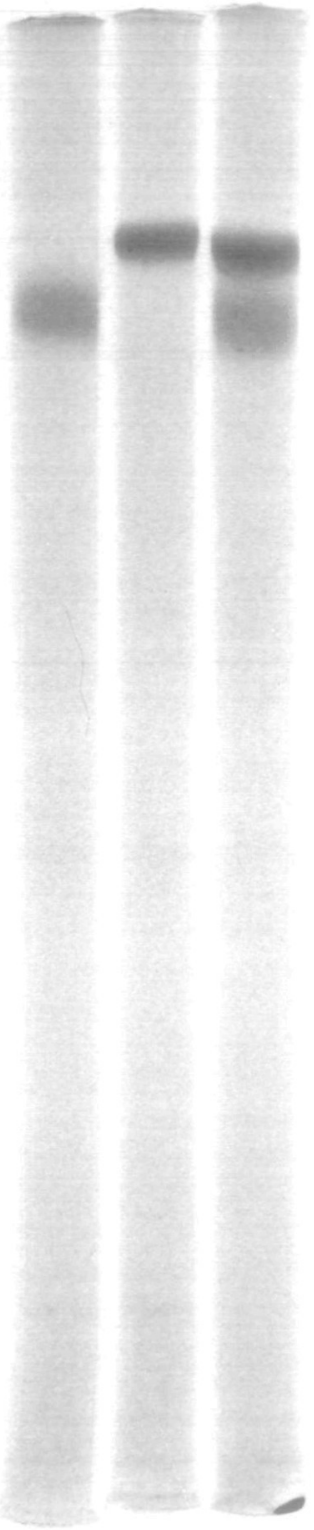

Fig. 4. Native gel electrophoresis of the purified arylmannosidases A and $B$. Proteins were applied to the gels and run as described in the text. Protein was detected by staining with Coomassie Blue. Lanes are as follows: lane 1, arylmannosidase A; lane 2, arylmannosidase B; lane 3 , mixture of arylmannosidase $\mathrm{A}$ and arylmannosidase $\mathrm{B}$.

buffer below $\mathrm{pH} 5.5$, it lost considerable activity and the extent of loss increased as the $\mathrm{pH}$ was lowered. Thus, at $\mathrm{pH}$ $4.5 \sim 50 \%$ of the activity was lost in 1 week, whereas at $\mathrm{pH}$ $4.0>85 \%$ of the activity was gone in I week (data not shown).

\section{Properties of the purified arylmannosidases}

The release of mannose from $p$-nitrophenyl- $\alpha$-D-mannopyranoside was linear with time for up to $60 \mathrm{~min}$ and with the amount of protein up to $\sim 15 \mathrm{ug}$ of purified enzyme (with either arylmannosidase A or B; data not shown). The $\mathrm{pH}$ optimum for both arylmannosidase $\mathrm{A}$ and aryl-
A
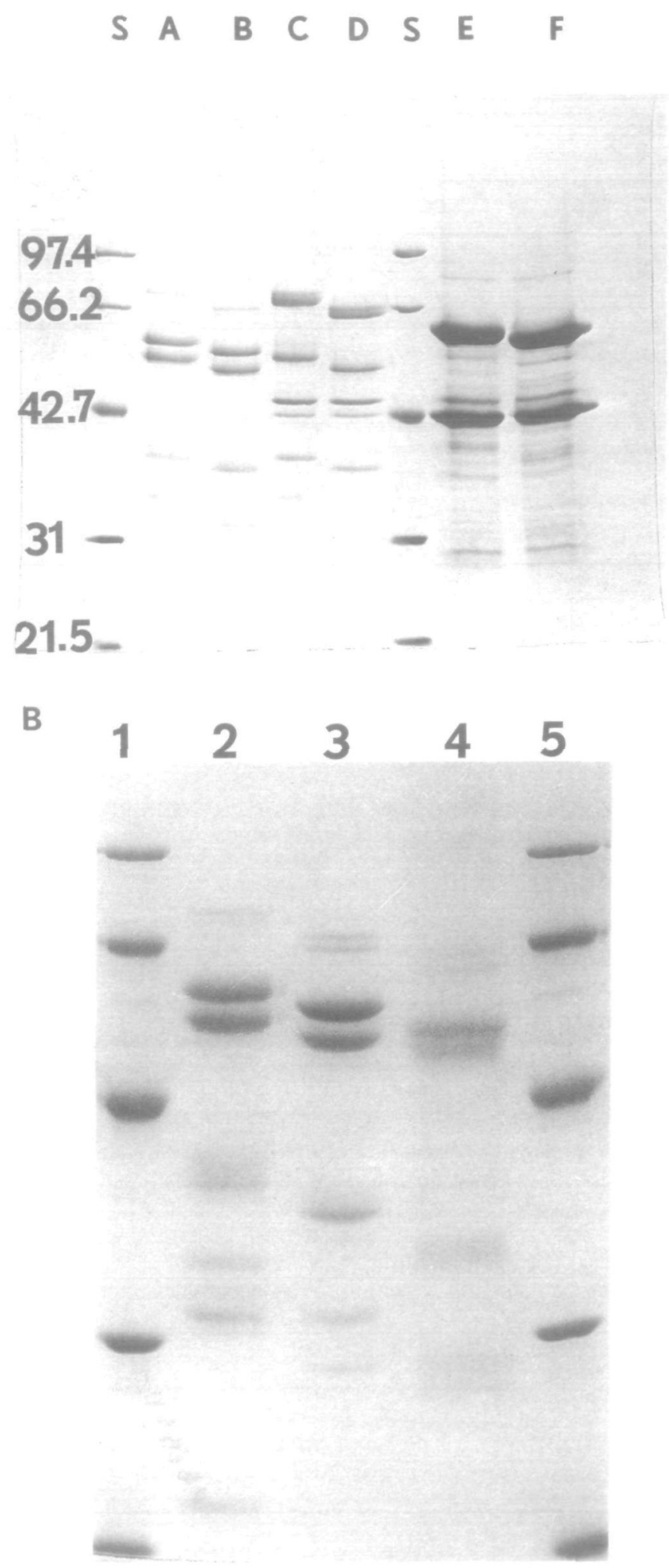

Fig. 5. (A) SDS gel electrophoresis of purified arylmannosidases $A$ and B. The purified enzymes were subjected to SDS gel electrophoresis, etther before (lanes A, C and E) or after (lanes B, D and F) digestion with Endo $H$. Protems were stained with Coomassie Blue. Lanes $A$ and $B$ are from arylmannosidase $A$; lanes $C$ and $D$ from arylmannosidase $B$; lanes $E$ and $F$ from jack bean $\alpha$-mannosidase. Standards shown in lane $\mathrm{S}$ are as follows phosphorylase b, $97.4 \mathrm{kd}$; bovine serum albumin, 66.2 kd; ovalbumin, $42.6 \mathrm{kd}$; carbonic anhydrase, $31 \mathrm{kd}$; trypsin inhibitor, $21.5 \mathrm{kd}$. (B) Gel electrophoresis of arylmannosidase A after release of oligosaccharides by hydrolysis with TFMS (lane 4). Lanes 1 and 5 are standards; lane 2 is untreated arylmannosidase A; lane 3 is enzyme treated with endo $H$; lane 4 is enzyme treated with TFMS. 


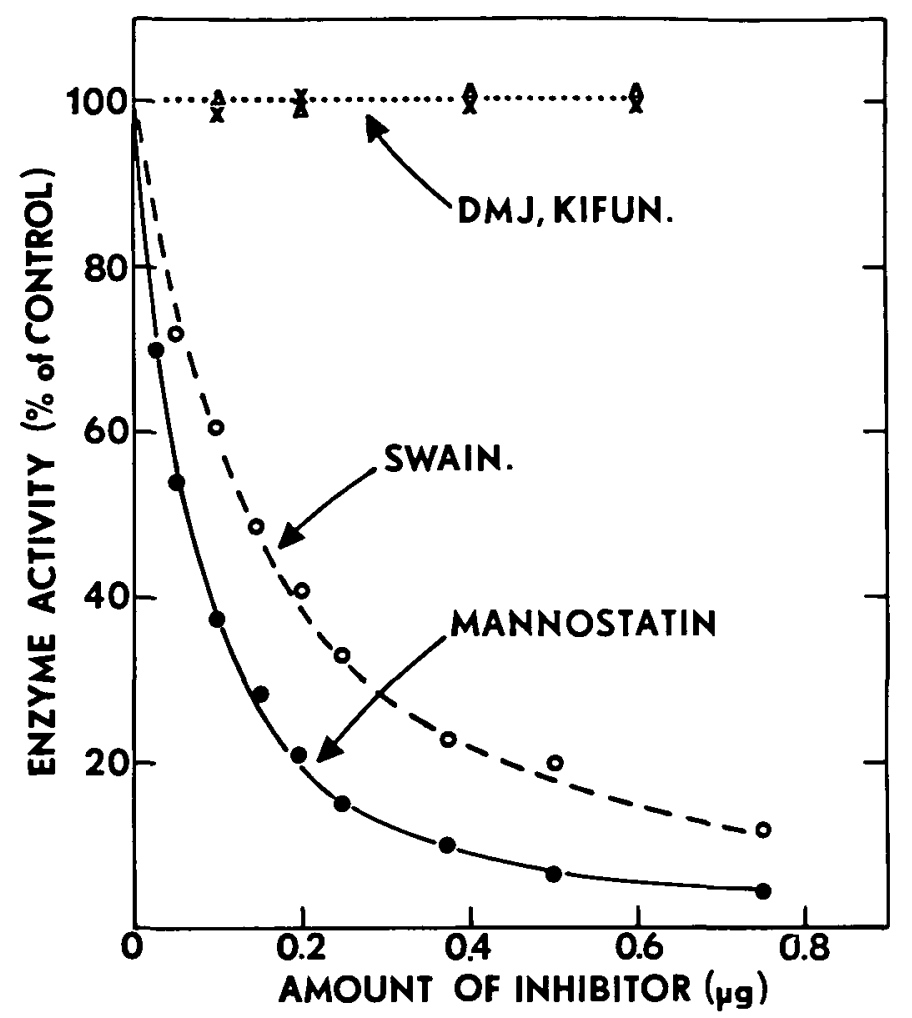

Fig. 6. Effect of various processing inhıbitors on the activity of arylmannosidases. Various amounts of the inhibitors were added as indicated in the figure. The reaction mixtures were as described in the text, with $p$-nitrophenyl- $\alpha$-D-mannopyranoside as the

substrate. The release of $p$-nitrophenol was measured at $410 \mathrm{~nm}$. The experiment shown here was done with arylmannosidase $\mathrm{A}$, but arylmannosidase $B$ gave essentially the same results.

mannosidase B was somewhat broad, between 3.5 and 5.0, shown using either citrate-phosphate buffer or acetate buffer. However, activity rapidly declined above $\mathrm{pH} 5.0$ and below 3.5 (data not shown). The effect of concentration of the substrate, $p$-nitrophenyl- $\alpha$-D-mannopyranoside, on the activity of arylmannosidases A and B was determined. Enzyme activity increased with increasing substrate concentration up to $\sim 8 \mathrm{mM}$ and then slowly leveled off at higher concentrations of substrate. When the data were plotted by the method of Lineweaver and Burk, the $K_{\mathrm{m}}$ for $p$-nitrophenyl- $\alpha$-D-mannopyranoside was calculated to be 3.3 for either enzyme.

We also compared the reactivity of arylmannosidase $\mathrm{A}$ to that of arylmannosidase $B$ in terms of release of mannose units from a mannose-labeled $\mathrm{Man}_{9}$ GlcNAc substrate. At low concentrations of enzyme, arylmannosidase A could release most of the mannose from this substrate, and gave rise mostly to Man- $\beta$-GlcNAc and free mannose over a $24 \mathrm{~h}$ incubation. However, with arylmannosidase B (using an amount of enzyme giving the same reactivity towards $p$ nitrophenyl- $\alpha$-mannopyranoside as used with $A$ ) there were still considerable amounts of $\mathrm{Man}_{4}$ GlcNAc and $\mathrm{Man}_{3} \mathrm{GlcNAc}$, even after $25 \mathrm{~h}$ of incubation, suggesting that the B enzyme probably acts more slowly on $\alpha 1,3-$ and $\alpha 1,6$-mannosidic linkages than the A enzyme (data not shown). Detailed kinetic studies with these enzymes have not yet been done but will be of interest to understand their mechanism of catalysis.

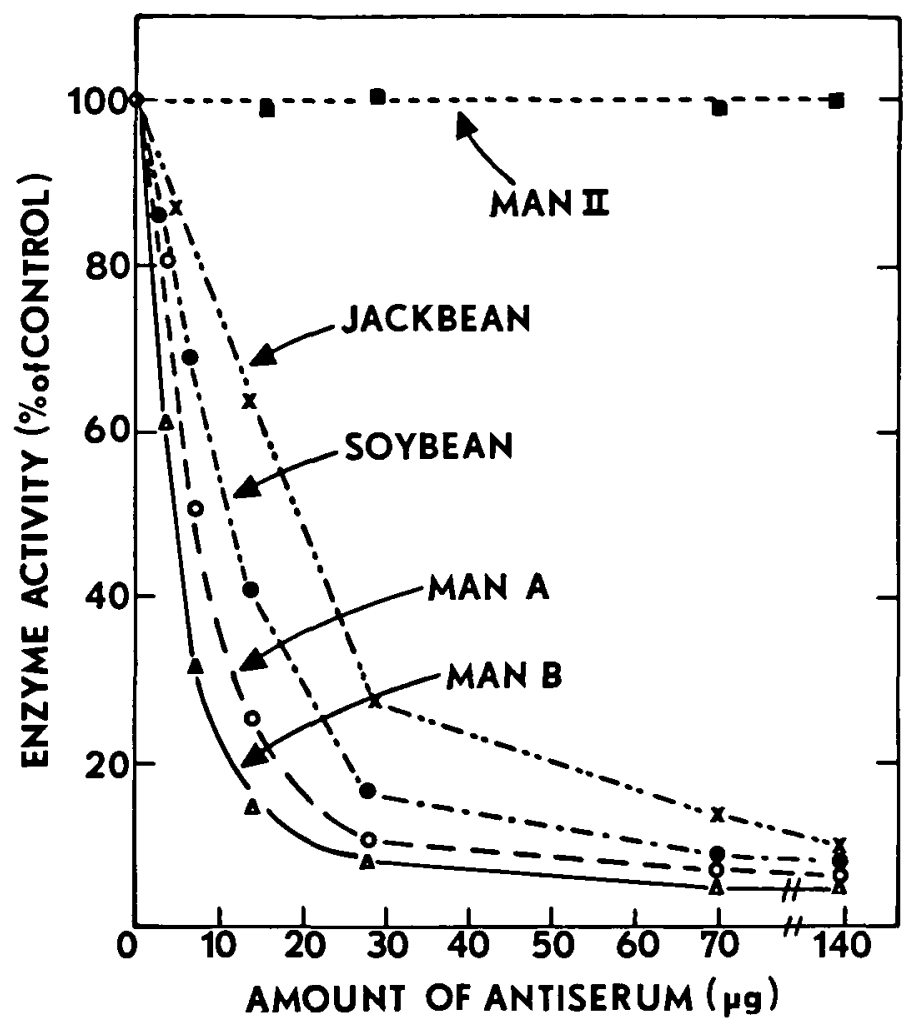

Fig. 7. Effect of polyclonal antibody against arylmannosidase B on the immunoprecipitation of various mannosidases. Mannosidases prepared from mung bean seedlings, cultured soybean cells or jack beans (commercially obtained) were incubated with various amounts of antimannosidase B antibody. After 2-3 h of incubation, S. aureus was added. The suspension was kept at $4^{\circ} \mathrm{C}$ for $1.5 \mathrm{~h}$ with occasional stirring. The mixture was centrifuged for $2 \mathrm{~min}$ and the enzymatic activity remaining in the supernatant liquid determined as described in the text.

\section{Effect of various mannosidase inhibitors on the arylmannosidases}

We examined the effects of various inhibitors of mannosidase I and mannosidase II on the purified mung bean arylmannosidases, as shown in Figure 6. It can be seen that the inhibitors of mannosidase II and jack bean $\alpha$-mannosidase, i.e. swainsonine (Tulsiani et al., 1982b; Kang and Elbein, 1983) and mannostatin (Tropea et al., 1990), were very good inhibitors of the mung bean arylmannosidases, whereas inhibitors of mannosidase I, i.e. deoxymannojirimycin (Fuhrmann et al., 1984) and kifunensine (Elbein et al., 1990), were inactive towards the arylmannosidases. Clearly the best inhibitor was mannostatin which showed an $\mathrm{IC}_{50}$ of $\sim 1 \times 10^{-7} \mathrm{M}$ for this enzyme when p-nitrophenyl$\alpha$-D-mannopyranoside was used as the substrate. Swainsonine was somewhat less effective and gave an $\mathrm{IC}_{50}$ of $\sim 5$ $\times 10^{-7} \mathrm{M}$.

\section{Preparation of antibody against arylmannosidases $A$ and arylmannosidase $B$}

Purified arylmannosidase B, as seen in Figure 4, was injected into a rabbit for the preparation of polyclonal antibody. This antibody was then tested to determine its specificity towards several different enzyme preparations and extracts 


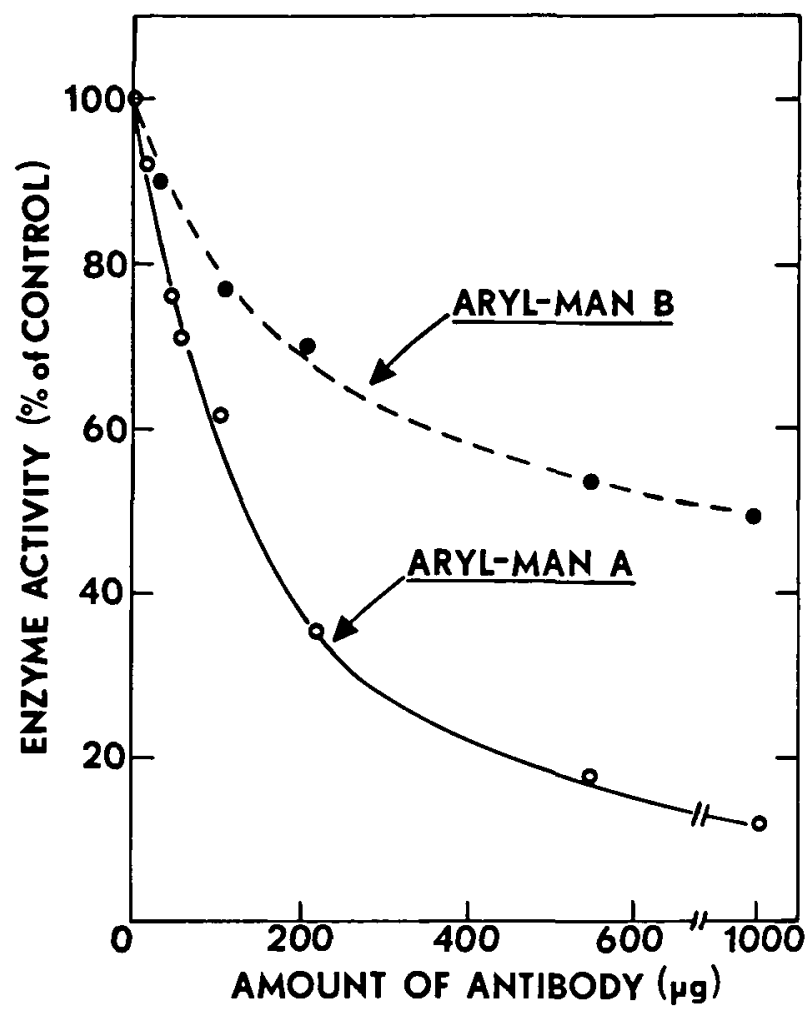

Fig. 8. Effect of monoclonal antibody agaınst arylmannosidase $A$ on the immunoprecipitation of arylmannosidases $A$ and $B$ from solution. Arylmannosidases $A$ and $B$ were incubated with various amounts of monoclonal antıbody for several hours and then $S$. aureus was added. After an incubation, with occasional stirring for several hours, the precipitate was removed by centrifugation and the supernatant liquid assayed for mannosidase activity.

from various organisms. These results are shown in Figure 7. In this experiment various amounts of the antibody were incubated with the indicated extract or enzyme preparation, and then $S$. aureus was added to precipitate the antigenantibody complex. After centrifugation to remove the precipitated antigen, the supernatant liquid was assayed for remaining arylmannosidase activity using $p$-nitrophenyl- $\alpha$ D-mannopyranoside as substrate. It can be seen that the polyclonal antibody prepared against arylmannosidase $\mathbf{B}$ was equally as effective against the purified arylmannosidase $A$, and was also very effective against arylmannosidase activity in extracts from suspension-cultured soybean cells. Interestingly enough, the antibody also reacted with $\bar{a}$ commercial preparation of jack bean $\alpha$-mannosidase, although it was not nearly as effective towards this enzyme as it was on the mung bean enzymes. The SDS gels of jack bean $\alpha$-mannosidase shown in Figure 5 do indicate that this enzymes shares at least one common subunit with the mung bean arylmannosidases. The arylmannosidase $B$ antibody did not react with either of the purified mung bean processing mannosidases, mannosidase I (Szumilo et al., 1986a) and mannosidase II (Kaushal et al., 1990), indicating that these Golgi mannosidases are distinct from the arylmannosidases.

We also prepared a monoclonal antibody against arylmannosidase $\mathrm{A}$ by injecting this enzyme into a mouse and screening hybridomas for their ability to produce an antibody that would precipitate arylmannosidase A from solution. Figure 8 shows the results obtained with the mono- clonal antibody tested against purified arylmannosidases $\mathrm{A}$ and $B$. While the antibody was quite effective at precipitating arylmannosidase A from solution (in the presence of $S$. aureus), it was much less effective against arylmannosidase $B$, although it still had some activity towards this protein. This is further evidence that arylmannosidases $A$ and $B$ are distinct proteins although they must share some common epitope(s). On the other hand, the monoclonal antibody had no activity towards jack bean $\alpha$-mannosidase, or against mannosidases I and II. This monoclonal antibody could not be used for immunoblotting the arylmannosidases on SDS gels since it apparently does not recognize the denatured proteins. It can, however, be used to detect the proteins on native gels.

\section{Characterization of the carbohydrate structure of the soybean arylmannosidases}

Since the polyclonal antibodies directed against the mung bean arylmannosidases ( $\mathrm{A}$ and $\mathrm{B}$ ) also cross-reacted with protein(s) from extracts of suspension cultured soybean cells, we used this antibody to isolate $\left[{ }^{3} \mathrm{H}\right]$-mannose-labeled arylmannosidase from cultured soybean cells in order to determine the carbohydrate structure of these enzymes. Thus, soybean cells were grown in the presence of [2${ }^{3} \mathrm{H}$ ]mannose for $\sim 24 \mathrm{~h}$, as previously described (Hori and Elbein, 1983), and cell-free extracts were prepared. The arylmannosidase was partially purified by DEAE-cellulose and hydroxylapatite chromatography, and the labeled arylmannosidase was then immunoprecipitated with the polyclonal antibody. The labeled immunoprecipitate was suspended in $0.5 \%$ SDS containing $5 \mathrm{mM} \beta$-mercaptoethanol and heated at $100^{\circ} \mathrm{C}$ for $5 \mathrm{~min}$. After cooling and diluting the mixture to $0.1 \%$ SDS, it was incubated with endoglucosaminidase $\mathrm{H}$ to release high-mannose or hybrid types of $\mathrm{N}$-linked oligosaccharides. The reaction was stopped by the addition of trichloroacetic acid (TCA) to a final concentration of $5 \%$, and the protein was removed by centrifugation. The supernatant liquid, containing the Endo $\mathrm{H}$ released oligosaccharides, was removed and saved, and the precipitated protein was washed several times with $50 \%$ methanol to remove the TCA. This protein was digested exhaustively with pronase to obtain glycopeptides representing the Endo $\mathrm{H}$-resistant oligosaccharides. The amount of radioactivity in the oligosaccharides released by Endo $\mathrm{H}$ was $\sim 55250$ c.p.m., compared with 62300 c.p.m. remaining with the protein after Endo $\mathrm{H}$ and released by pronase digestion of the precipitate. Assuming these are three mannose residues in the Endo $\mathrm{H}$ resistant oligosaccharides as compared with six to eight mannose residues in the Endo $\mathrm{H}$-sensitive structures, the ratio of resistant chains to sensitive chains is $\sim 2$ or $3: 1$.

The Endo H-released oligosaccharides were chromatographed on a long, calibrated column of Biogel P-4, as seen in Figure 9. The major radioactive peak corresponded to a hexose $_{8-9}$ GlcNAc, while the next major peak was in the

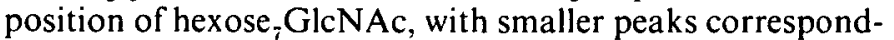
ing to hexose ${ }_{6}$ GlcNAc and Glc Man $_{9}$ GlcNAc. The lower profile of Figure 9 demonstrates that the oligosaccharide mixture was almost completely susceptible to digestion by jack bean $\alpha$-mannosidase, indicating that these oligosaccharides were essentially all high-mannose structures. 


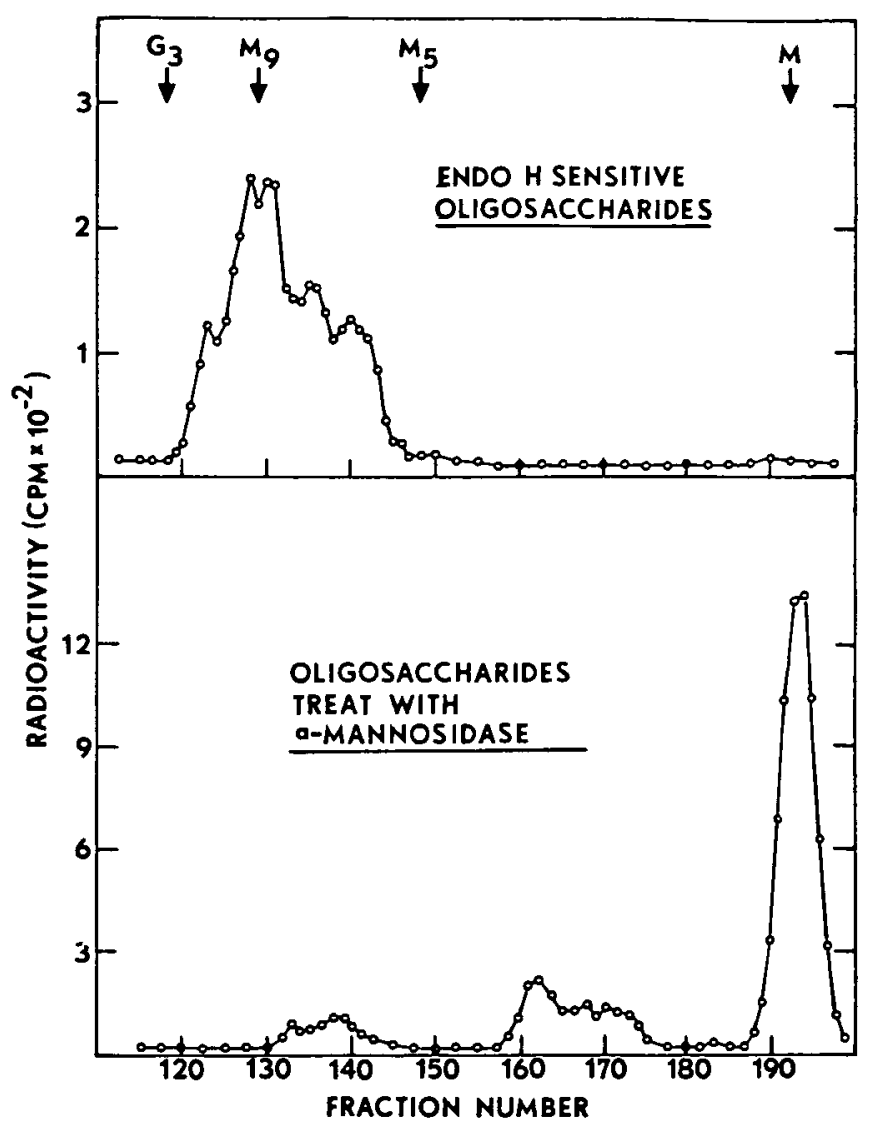

Fig. 9. Characterization of the oligosaccharıdes of soybean arylmannosidase released by digestion with endoglucosaminidase $\mathrm{H}$. Soybean cells were labeled with $\left[2{ }^{3} \mathrm{H}\right]$ mannose and arylmannosidase was isolated by chromatography on DEAE-cellulose and then by immunoprecipitation. The radiolabeled immunoprecipitate was treated with Endo $\mathrm{H}$ and the reaction was stopped by the addition of TCA. The precipitate was removed by centrifugation and saved to isolate Endo H-resistant glycopeptides and the supernatant liquid extracted with ethyl ether to remove TCA and applied to a column of Biogel P-4 (upper profile) Fractions were collected and assayed for their radioactive content. The entire radioactive peak (fractions 120-145) was pooled, digested exhaustıvely with $\alpha$-mannosidase and rechromatographed on the Biogel P-4 column (lower profile). The arrows indicate the various oligosaccharide standards used to calibrate the column; $\mathrm{G}_{3}=\mathrm{Glc}_{3} \mathrm{Man}_{9}$ GlcNAc; $\mathrm{M}_{9}=\mathrm{Man}_{8}$ GlcNAc; $\mathrm{M}_{5}=$ $\mathrm{Man}_{5}$ GlcNAc, $\mathrm{M}=$ mannose.

This was also confirmed by chromatography on columns of Concanavalin A-Sepharose, as shown in Figure 10. It can be seen by the upper profile that essentially all of the radioactivity bound tightly to the Concanavalin A column and required $500 \mathrm{mM}-\alpha$-methylmannoside to be released. This is typical behavior for high mannose oligosaccharides (Cummings and Kornfeld, 1982).

The glycopeptides released by pronase digestion were also chromatographed on the Biogel P-4 columns, as seen in Figure 11 . In this case the radioactivity emerged in three peaks, labeled A, B and C (upper profile). The major peak, designated peak B, emerged near the $\mathrm{Man}_{9}$ GlcNAc standard indicating a mol.wt of $\sim 1800$. The next largest peak emerged before the $\mathrm{Man}_{5}$ GlcNAc standard, suggesting a mol.wt of $\sim 1300$. A small peak of radioactivity also emerged near the $\mathrm{Glc}_{3} \mathrm{Man}_{9}$ GlcNAc standard. Each of these peaks was pooled separately and treated exhaustively with jack bean $\alpha$-mannosidase. The lower profile in Figure 11 shows the results obtained with glycopeptide B. It can be

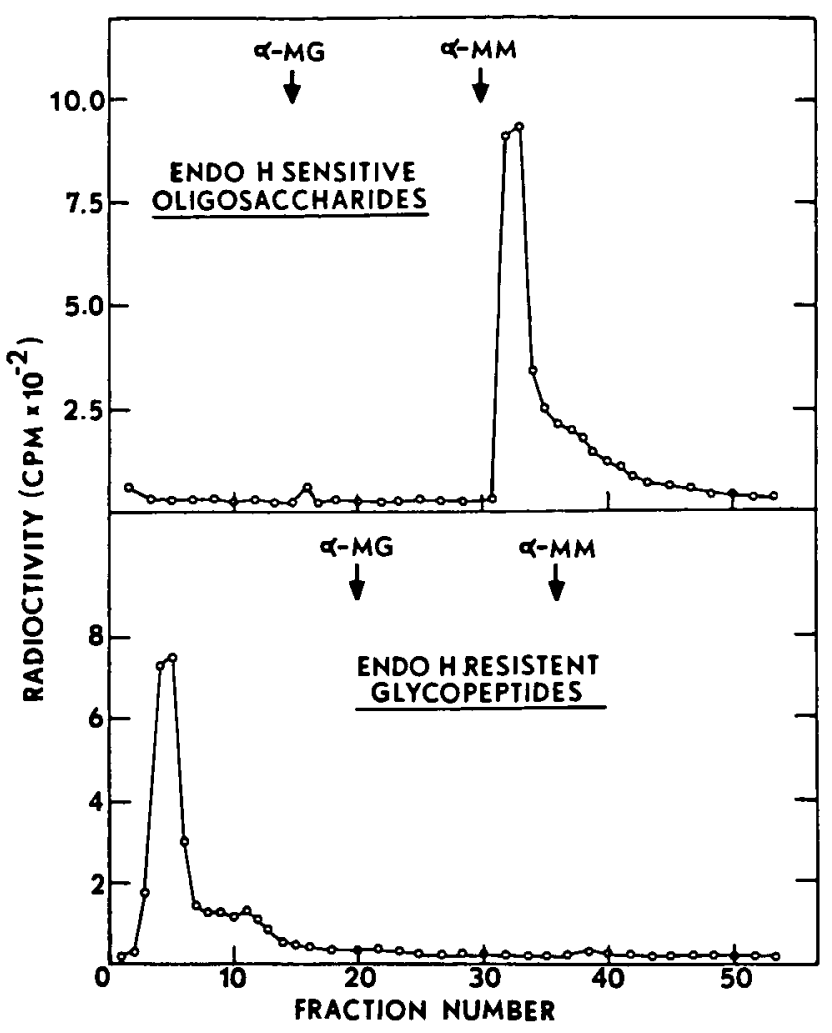

Fig. 10. Characterization of oligosaccharides and glycopeptudes by chromatography on Concanavalin A-Sepharose The radiolabeled oligosaccharides or glycopeptides from Biogel P-4 were

chromatographed on $2 \mathrm{ml}$ columns of Concanavalin A-Sepharose. Unbound material was removed in the buffer wash $(20 \mathrm{mM}$ Tris- $\mathrm{HCl}$ buffer, pH 7.2, containing $200 \mathrm{mM} \mathrm{NaCl}, 1 \mathrm{mM} \mathrm{MnCl}, 1 \mathrm{mM} \mathrm{MgCl}_{2}$, and $1 \mathrm{mM} \mathrm{CaCl}$ ). The columns were then eluted with $10 \mathrm{mM} \alpha-$ methylglucoside to remove biantennary and some hybrid structures, and then with $200 \mathrm{mM} \alpha$-methylmannoside to elute high-mannose and hybrid chains. The upper profile is that from the Endo $\mathrm{H}$-sensitive oligosaccharides of Figure 9, while the lower profile is that from the Endo H-resistant glycopeptides of Figure 11.

seen that the enzyme caused the release of some radioactive mannose, as shown by the slow moving peak running with the mannose standard. In addition, the migration of the remaining oligosaccharide peak was shifted to a slower moving area, suggesting the loss of one hexose. Similar results were obtained with the other two glycopeptide peaks, i.e. a release of a small amount of radioactive mannose and a shift in migration that would be indicative of the loss of one hexose (data not shown). Thus the Endo H-resistant peaks appear to have one accessible mannose for the jack bean $\alpha$-mannosidase to release.

\section{Demonstration of xylose in the arylmannosidase subunits}

Since an antibody is available that specifically recognizes the xylose on the $\mathrm{N}$-linked oligosaccharides (Lauriere et al., 1989), we used this antibody to determine whether the various subunits of arylmannosidase $A$ and $B$ contained xylose. The results of this experiment are shown in Figure 12. Arylmannosidase $A$ and $B$, from both mung bean seedlings and suspension cultured soybean cells, were subjected to SDS gel electrophoresis, and the proteins were transferred to Immobilon and treated with either the polyclonal antibody against mannosidase B (gels on the right) or with the xylose-recognizing antibody (gels on left). 


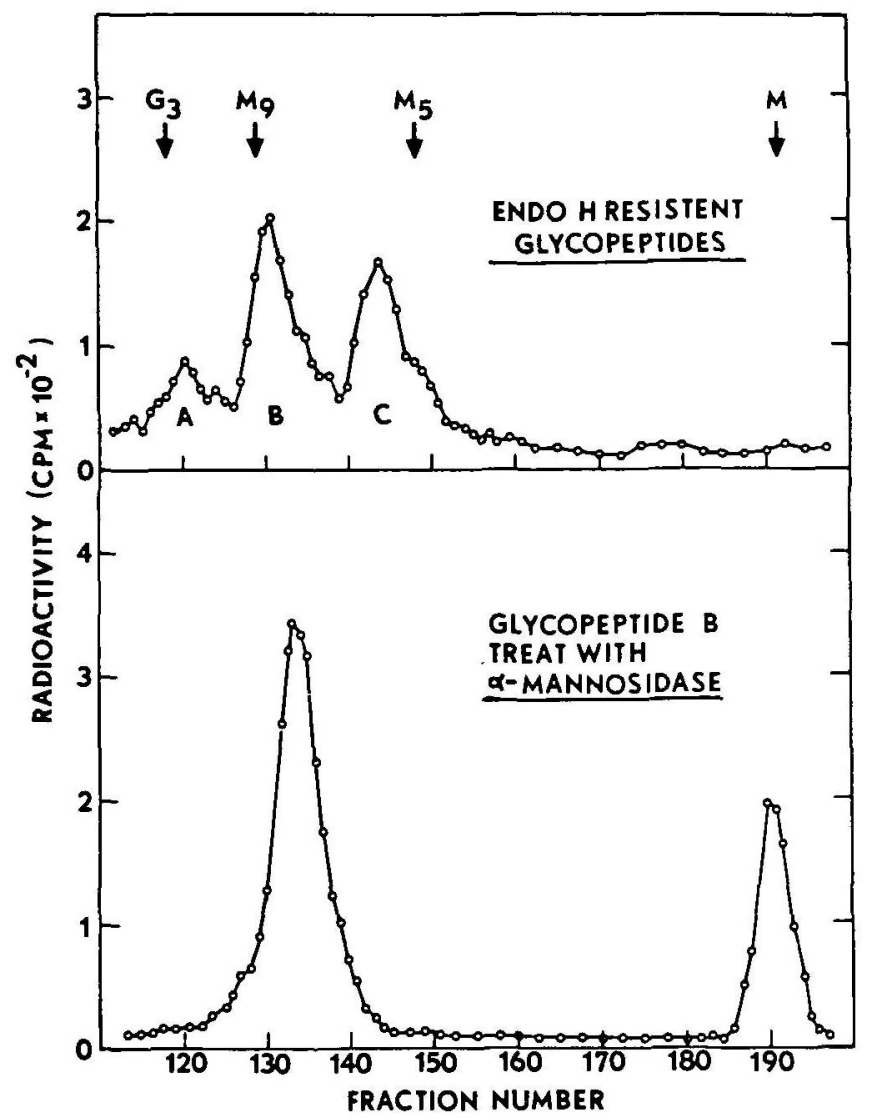

Fig. 11. Partial characterization of the Endo H-resistant glycopeptıdes. The glycopeptides released from the TCA-precipitated proten were chromatographed on a $1 \times 150 \mathrm{~cm}$ column of Biogel P-4. Aliquots of each fraction were removed for the determination of radioactivity (upper profile) and individual peaks pooled for further analysis. In the lower profile glycopeptide B was treated exhaustıvely with jack bean $\alpha$ mannosidase and the digest rechromatographed on the Biogel column.

The antibody binding proteins were then visualized by reacting with peroxidase-labeled anti-rabbit antibody. It can be seen by comparing the gels that each of the subunits of both arylmannosidase $\mathrm{A}$ and arylmannosidase $\mathrm{B}$ reacted with both the polyclonal antibody and with the xyloserecognizing antibody. Since with one or two exceptions, each of the subunits was also susceptible to Endo $\mathrm{H}$, it seems likely that each of these proteins has at least 2 oligosaccharide chains, one of which is high-mannose and the other a modified xylose-containing structure. It should be pointed out that it is possible that our polyclonal antibody also contains antibodies that recognize xylose or other carbohydrate epitopes.

\section{Discussion}

Plant cells contain a number of different $\alpha$-mannosidase activities, which apparently have varied functions. The mannosidases whose function is best understood are those involved in glycoprotein processing mannosidases I (Szumilo et al., 1986a) and II (Kaushal et al., 1990), which are located in the Golgi complex and serve to remove $\alpha$-linked mannose residues from $\mathrm{N}$-linked oligosaccharides in order to produce various modified structures (Kornfeld and Kornfeld, 1985). In addition, there are a number of less specific $\alpha$ mannosidases in plant cells that are generally referred to as

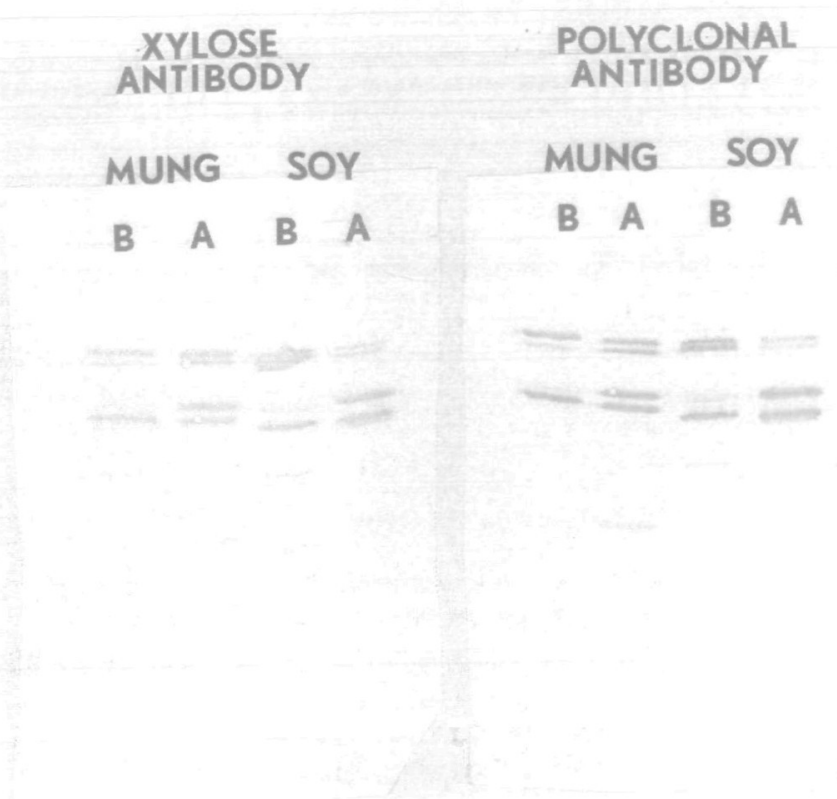

Fig. 12. Comparison of Western blots of arylmannosidases $A$ and $B$ using anti-arylmannosidase $B$ polyclonal antibody and antibody directed against the xylose portion of the modified oligosaccharides. Purified arylmannosidases A and B were subjected to SDS gel electrophoresis and the proteins transferred to Immobilon and treated with the indicated antibodies as described in the text.

arylmannosidases because they can be assayed with the synthetic substrate, $p$-nitrophenyl- $\alpha$-mannopyranoside (McGee and Murray, 1985). The function of these enzymes is less clear, although they are synthesized in the ER, transported through the Golgi and packaged into the protein bodies (Van der Wilden and Chrispeels, 1983; Faye et al., 1988). We assume that the two arylmannosidases described here are protein body or vacuolar enzymes. We are in the process of doing enzyme localization studies on these proteins using immunocytochemical methods to determine where the bulk of the enzymes are located in soybean cells.

In some cases the arylmannosidases have been found to be closely associated with the cell wall, and extensive washing with a buffer of low ionic strength did not remove an appreciable amount of the activity (Greve and Ordin, 1977). Arylmannosidase was also detected in the vacuoles isolated from protoplasts of cells of tobacco cell-suspension culture, tulip petals and pineapple leaves (Boller and Kende, 1979). The lytic function of vacuoles suggests an analogy with animal lysosomes (Nichimura and Beevers, 1978). Thus, one would suspect that the vacuolar mannosidases are involved in turnover of $\mathrm{N}$-linked glycoproteins, just like the lysosomal mannosidases of animal cells. However, the function of the cell wall mannosidases is not so clear. They could be involved in a protective function to prevent attachment or invasion of pathogens, or they could be artifacts of growing cells in culture; or, since cell walls have been postulated to have a lytic function, they could be involved in such a role (Greve and Ordin, 1977). In animal cells, a portion of the lysosomal enzymes that are normally targeted from the endoplasmic reticulum to the lysosomes are apparently mistargeted to the cell surface and ultimately are found in the medium (Kornfeld, 1990). 
During the course of our studies on the purification and properties of the processing mannosidases in mung bean seedlings, we detected two arylmannosidases in extracts of this plant. These two enzymes were purified to homogeneity and their structures and properties were examined. The native enzymes were similar in mol.wt to that from $M$. sativa (216000-226000) (De Prijker et al., 1974), and some of the subunits were also similar in size to those from $M$. sativa. However, the mol.wts of arylmannosidases from plants have been reported to be as high as 630000 in $A$. sativa (Greve and Ordin, 1977), and as low as 170000 in soybean (Saita et al., 1971). Essentially all of the plant arylmannosidases appear to be glycoproteins and are probably of the $\mathrm{N}$-linked type, although no glucosamine was detected in the enzymes from Phaseolus vulgaris (Paus, 1977)

Since we used antibody against the mung bean arylmannosidases and this antibody cross-reacted with arylmannosidase activity from suspension-cultured soybean cells, we could use it to isolate biosynthetically radiolabeled enzyme, in order to study the formation and structure of the carbohydrate portion of these molecules. After labeling soybean cells for $24 \mathrm{~h}$ in $\left[2-{ }^{3} \mathrm{H}\right]$ mannose, the enzyme was isolated by immunoprecipitation and treated with endoglucosaminidase $\mathrm{H}$. This enzyme released $\sim 50 \%$ of the radioactivity as high mannose oligosaccharides of the $\operatorname{Man}_{9-7}(\mathrm{GlcNAc})_{2}$ type. The remaining $50 \%$ of the radioactivity was released as glycopeptides when the Endo $\mathrm{H}$ treated protein was digested with pronase. This Endo $\mathrm{H}$ resistant glycopeptide(s) did not bind to Concanavalin A and was only slightly susceptible to $\alpha$-mannosidase, probably losing only one mannose by this treatment. Although we do not know the exact structure of these modified chains, it is likely that they are the xylose-containing structures that give rise to immunoblotting of each subunit by the xylose antibody. Further biosynthetic studies, as well as some structural characterization, will be necessary to determine the number of oligosaccharide chains on each subunit and how many of them carry xylose. In addition, such studies should provide information on when and where xylose is added and help us to understand its role in the function of these enzymes.

Some biosynthetic studies in plants have provided valuable information on $\mathrm{N}$-linked glycosylation of proteins. For example, the biosynthesis of phaseolin, a reserve glycoprotein stored in protein bodies of $P$. vulgaris seeds, has been examined in various subcellular compartments using phaseolin antibodies. Four precursor polypeptides of phaseolin were detected in the endoplasmic reticulum when the developing cotyledons were labeled with $\left[{ }^{3} \mathrm{H}\right] \mathrm{amino}$ acids, $\left[{ }^{3} \mathrm{H}\right]$ glucosamine and $\left[{ }^{3} \mathrm{H}\right]$ mannose, indicating that glycosylation of phaseolin occurs in the endoplasmic reticulum (Bollini et al., 1983). Additional in vitro experiments using a wheatgerm translation system and isolated polysomes and ER membranes demonstrated that glycosylation is a cotranslational event (Bollini et al., 1983). Similar biosynthetic experiments were performed in the case of the lectin, phytohemagglutinin, a tetrameric glycoprotein of $P$. vulgaris. In this case, each of the four polypeptide chains is cotranslationally glycosylated at two different sites. Only high-mannose chains are present in the proteins in the ER but one of the high-mannose chains in each is modified in the Golgi body, where fucose and GlcNAc residues are incorporated before the glycoprotein is transferred to protein bodies (Vitale and Chrispeels, 1984). Nevertheless, the role of carbohydrate in these proteins is still not known. Since xylose is a unique substituent found only in plants and some lower animals, its presence suggests some specific function. Further studies on the biosynthesis and targeting of these mannosidases, as well as studies on the alteration of carbohydrate structure with various processing inhibitors, should help us to understand the role of N-linked oligosaccharides.

\section{Materials and methods}

\section{Materials}

$\left[6-{ }^{3} \mathrm{H}\right]$ Galactose $(20 \mathrm{Ci} / \mathrm{mmol})$ and $\left[2{ }^{3} \mathrm{H}\right]$ mannose $(15 \mathrm{Cl} / \mathrm{mmol})$ were purchased from American Radiolabeled Chemicals or from New England Nuclear, Inc. Nitrocellulose, Biobeads SM-2, Horseradish peroxidaseconjugated goat antı-rabbit $\operatorname{IgG}(\mathrm{H}+\mathrm{L})$ antıbody and rabbit antı-mouse $\lg G(\mathrm{H}+\mathrm{L})$, Biogel P-4 (200-400 mesh), hydroxyapatite (Biogel HT), acrylamide, bis-acrylamide, sodium dodecylsulfate and mol.wt standards were obtained from Biorad. Concanavalın A-Sepharose, 4-chloro-1naphthol, dithiothreitol, leupeptin, 1,10-phenanthroline, phenylmethylsulfonyl fluoride (PMSF), $p$-nitrophenyl- $\alpha$-D-mannopyranoside and other p-nitrophenylglycosides were from Sigma Chemical Co. Glycopeptidase F and Staphylococcus aureus were purchased from Boehringer Co. Endo- $\beta$ $N$-acetylglucosamınidase $\mathrm{H}$ was from ICN Immunobiologicals, Immobilon P membranes from Millipore and DEAE cellulose (DE-52) from Whatman Chemical Separation, Ltd. Castanospermine was isolated from the seeds of Castanospermum australe as previously described (Hohenschutz et al., 1981) and swainsonine was isolated from the leaves of Astragalus lentrginosus (Molyneux and James, 1982). Deoxymannojirimycin was purchased from Genzyme, and mannostatin was generously supplied by Dr T.Aoyagi, Microbial Chemistry Research Foundation, Tokyo, Japan. All other chemicals were obtained from reliable chemical sources and were of the best grade available.

\section{Preparation of membrane fraction from mung bean seedlings}

Mung beans were soaked in tap water overnight at $25^{\circ} \mathrm{C}$, spread on moist paper towels and placed in the dark for 2 or 3 days for germination. The seedlings were picked by hand and placed in ice. One kilogram of seedlings were blended in $500 \mathrm{ml}$ of $50 \mathrm{mM}$ HEPES buffer, pH 7.4, containing 0.25 $M$ sucrose, $0.5 \mathrm{mM}$ dithiothreitol, $1 \mathrm{mM}$ EDTA and $0.5 \%$ polyvinylpyrrolidone, for $10 \mathrm{~s}$ (three times) in a Waring blendor. The resulting suspension was filtered through eight layers of cheesecloth, and the filtrate was centrifuged at $3000 \mathrm{~g}$ for $10 \mathrm{~mm}$ to remove whole cells and large particles. The supernatant liquid from this centrifugation was then centrifuged at $100000 \mathrm{~g}$ for $45 \mathrm{~min}$ to isolate the membrane fraction. Arylmannosidase activity was found in the soluble (cytoplasmic) fraction and in the microsomal fraction, but much more activity was in the soluble form. The enzymes (both $A$ and $B$ ) were purified from both sources and compared.

\section{Solubilization of aryl- $\alpha-$ mannosidases}

The membrane pellet was washed with $50 \mathrm{mM}$ HEPES buffer, pH 7.4, containing $0.1 \%$ Triton $X-100$, and was then centrifuged at $100000 \mathrm{~g}$ for $45 \mathrm{~min}$. The resulting pellet was resuspended in HEPES buffer, $\mathrm{pH} 7.4$, containing $5 \%$ glycerol, $0.5 \mathrm{mM}$ PMSF and $1.5 \%$ Triton $X-100$, and homogenized for $15 \mathrm{~min}$ in a Dounce homogenizer. The suspension was subjected to ultracentrifugation as before, and the supernatant liquid, containing the solubilized mannosidase activity, was removed and saved. The residue was re-extracted with the same solubilization buffer, and after centrifugation the supernatant liquid was pooled with the first supernatant.

\section{Assay for aryl-a-mannosidase activity}

The arylmannosidase was assayed by using $p$-nitrophenyl- $\alpha$-D-mannopyranoside as the substrate. The assay mixture contained $50 \mathrm{mM}$ sodium acetate buffer, $\mathrm{pH} 4.5$, and $5 \mathrm{mM}$-nitrophenyl- $\alpha$-mannoside, in a final volume of $0.2 \mathrm{ml}$. The incubation was at $37^{\circ} \mathrm{C}$ for varyıng periods of 
tıme, and the reaction was stopped by the addition of $2.5 \mathrm{ml}$ of $0.4 \mathrm{M}$ glycine buffer, $\mathrm{pH} 10.4$. The amount of $p$-nitrophenol was measured by its absorbance at $410 \mathrm{~nm}$. In some experiments, the purified enzyme was tested with various radioactive mannose-containing oligosaccharides to determine whether it would release mannose from these substrates. $\left[{ }^{3} \mathrm{H}\right]$ Mannose-labeled $\mathrm{Man}_{9}$ GlcNAc was prepared by incubating influenza virus-infected Madin Darby canine kidney (MDCK) cells with deoxymannojirimycin, to inhibit mannosidase I (Fuhrmann et al., 1984), and labeling the glycoproteins with $\left[2{ }^{3} \mathrm{H}\right]$ mannose (Elbein et al., 1984). The isolated virus was digested with pronase to produce glycopeptides and the isolated glycopeptides were treated with endo- $\beta-N$-acetylglucosaminidase $\mathrm{H}$ to produce the $\mathrm{Man}_{9}$ GlcNAc. This substrate was purified by chromatography on a long $(1.5 \times 150 \mathrm{~cm})$, calibrated column of Biogel P-4. $\left[{ }^{3} \mathrm{H}\right]$ Mannose-labeled GlcNAc-Man ${ }_{5}$ GlcNAc was prepared by incubating the $\mathrm{Man}_{8}$ GlcNAc with partially purified mannosidase I (Szumilo et al., 1986a) to produce Man $_{5}$ GlcNAc, which was purified by gel filtration. The $\mathrm{Man}_{5}$ GlcNAc was then incubated with a partially purifed GlcNAc transferase I (Szumilo et al., 1986b) in the presence of UDP-GlcNAc to attach a GlcNAc to the 3-linked mannose branch (Harpaz and Schachter, 1980, Oppenheimer and Hill, 1981). Assay mixtures for these substrates usually contained $100 \mathrm{mM}$ MES buffer, $\mathrm{pH} 6.0,0.1 \%$ Triton X-100, 3500 c.p.m. of GlcNAc-Man ${ }_{5}$ GlcNAc or $\mathrm{Man}_{9}$ GlcNAc, $5 \mathrm{mM} \mathrm{CaCl}{ }_{2}$ when mannosidase I was assayed and various amounts of enzyme, all in a final volume of $0.2 \mathrm{ml}$ (Szumilo et al., 1986a; Kaushal et al., 1990). After incubation for the appropriate period of time, the reactions were stopped and deproteinized by the addition of $2.5 \%$ phosphotungstic acid and $5 \%$ trichloroacetic acid, and the release of free mannose was determined by a Concanavalın A-Sepharose binding assay (Szumilo and Elbein, 1985).

\section{Polyacrylamide gel electrophoresis}

Preparative polyacrylamide gel electrophoresis was performed at $4^{\circ} \mathrm{C}$ in tube gels containing 7\% acrylamide (Orr et al., 1972), using a TEA (triethanolamine)-TES $\{N$-[tris(hydroxymethyl)methyl]-2-aminoethanesulfonic acid $\}$ buffer system. The pHs of the stacking and resolving gels were maintained at 5.8 and 6.8 respectively. The tube gel apparatus and the buffers were cooled before use. SDS gel electrophoresis was performed according to the method of Laemmli (1970) in 10\% gels. Gels were stained for protein with $0.05 \%$ Coomassie Blue in $10 \%$ acetic acid containing $20 \%$ 2-propanol, and destained in a mixture of $10 \%$ 2-propanol and $10 \%$ acetic acid.

\section{Enzymatic digestions}

To obtain information about the carbohydrate structure of the arylmannosidases, the radiolabeled mannosidases were treated with various glycosidases to see what effects these enzymes would have on carbohydrate structure. For treatment with jack bean $\alpha$-mannosidase, the oligosaccharides (or the intact glycoproteins) were incubated in $50 \mathrm{mM}$ acetate buffer, $\mathrm{pH} 4.5$, containing $1250 \mathrm{mU}$ of jack bean $\alpha$-mannosidase and $1 \mathrm{mM}$ $\mathrm{ZnCl}_{2}$ for 24 hours under a toluene atmosphere. For endo- $\beta-N$. acetylglucosaminidase $\mathrm{H}$ digestions, the protein samples were denatured in $0.5 \% \mathrm{SDS}$ at $100^{\circ} \mathrm{C}$ for $5 \mathrm{~min}$. The samples were diluted 10 times with 50 $\mathrm{mM}$ citrate buffer, $\mathrm{pH} 6.0$, in order to dilute the SDS concentration to $0.05 \%$, and $10 \mathrm{mU}$ of Endo $\mathrm{H}$ were added. Incubations were at $37^{\circ} \mathrm{C}$ for $24 \mathrm{~h}$ under a toluene atmosphere. Products of these digestions were examined by gel filtration on columns of Biogel P-4, or by SDS gel electrophoresis.

\section{Other methods}

Protein concentration was measured by a Coomassie Blue procedure (Bradford, 1976). Oligosaccharides were separated and partially characterized on $1.5 \times 150 \mathrm{~cm}$ columns of Biogel P-4 (200-400 mesh) that had been calibrated with various oligosaccharide standards, including Glc $_{3} \mathrm{Man}_{8}$ GlcNAc, Man ${ }_{9}$ GlcNAc, Man ${ }_{5}$ GlcNAc, GlcNAc-Man ${ }_{5}$ GlcNAc and $\mathrm{Man}_{3} \mathrm{GlcNAc}$. Columns were equilibrated and run in $0.5 \%$ acetic acid at room temperature.

The mol.wt of the native a. sannosidases was determined by gel filtration on columns of Sephacryl S-300 and also by sedimentation velocity studies, whereas the mol.wt of the subunits was measured by SDS gel electrophoresis. A number of mol.wt standards were run on the column, including apoferritin $\left(\mathrm{M}_{r} 443000\right), \beta$-amylase $\left(\mathrm{M}_{r} 200000\right)$, alcohol dehydrogenase $\left(M_{r} 150000\right)$, bovine serum albumin $\left(M_{r} 66000\right)$ and carbonic anhydrase $\left(M_{r} 29000\right)$.

\section{Preparation and assay of antibody against arylmannosidase $B$}

Polyclonal antıbody against purified aryl- $\alpha$-mannosidase $B$ was prepared as follows: $25-30 \mu \mathrm{g}$ of protein in $0.5 \mathrm{ml}$ of phosphate-buffered saline was emulsified with an equal volume of Freund's complete adjuvant, and the mixture was injected at multiple sites along the back of a female rabbit. After 4 weeks a second injection of $25 \mu \mathrm{g}$ of enzyme, emulsified with Freund's incomplete adjuvant, was given. A third booster of another $25 \mu \mathrm{g}$ of arylmannosidase emulsified with Freund's incomplete adjuvant was given after another 4 weeks. Two weeks after this final injection, the rabbit was bled and the serum was collected and stored in aliquots at $-80^{\circ} \mathrm{C}$.

For monoclonal antibody production, a BALB/c mouse was immunized as above with arylmannosidase $A$. Three days after an intravenous boost in saline, the mouse was killed and the spleen cells were fused with $\mathrm{Sp} 2 / \mathrm{o}$ hybridoma cells using $50 \%$ polyethylene glycol as described (Harlow and Lane, 1988). Following selection and growth, specific antibody in the supernatants was assayed by an antibody capture ELISA assay (Harlow and Lane, 1988) using arylmannosidase $A$ as the antigen and horseradish peroxidase-conjugated rabbit anti-mouse Ig. Clones that were positive for binding were further analyzed by the immunoprecipitation assay described below. For further experiments, the monoclonal antibody selected, IA, was purified by ammonium sulfate precipitation and dialysis against phosphate buffered saline.

Antibody was tested for its reactivity with arylmannosidases by the precipitation assay The antibody was diluted in phosphate-buffered saline and various amounts of this antibody solution were incubated with the purified enzyme in Eppendorf tubes at $4^{\circ} \mathrm{C}$ for 3-4 h. Control tubes were also done with preimmune serum. At the end of this incubation, $20 \mathrm{ul}$ of a suspension of fixed Staphylococcus aureus ( $1 \mathrm{~g}$ of cells in $10 \mathrm{ml}$ of $\mathrm{H}_{2} \mathrm{O}$ ) was added and the mixture was allowed to stand for $1.5 \mathrm{~h}$ at $4^{\circ} \mathrm{C}$. The mixture was then centrifuged to remove the precipitated antibody (and antigen) and the enzyme activity in the supernatant fluid was tested. The control tubes served to show that preimmune serum did not contain inhibitory factors towards this enzyme and did not remove it from solution.

For the immunoblot analysis, the enzyme was resolved by SDS gel electrophoresis and proteins were electrophoretically transferred to nitrocellulose paper as described (Towbin et al., 1979). Subsequent blocking of nonspecific binding sites on the blot, antibody binding and further detection of the immunoreactive spots was done as described (Harlow and Lane, 1988).

\section{Acknowledgements}

This work was supported by a grant from the Robert A.Welch Foundation and grant DK 21800 from the National Institutes of Health. We would like to thank Dr Neal Robinson and Linda Talbert for performing the sedimentation velocity studies, and Mike Mitchell and Pat Schwartz for helpful suggestions and assistance with some of the experıments.

\section{References}

Boller,T. and Kende,H. (1979) Hydrolytıc enzymes in the central vacuole of plant cells. Plant Physiol., 63, 1123-1132.

Bollini,R., Vitale,A. and Chrispeels,M.J. (1983) In vivo and in vitro processing of seed reserve protein in the endoplasmic reticulum; evidence for two glycosylation steps. J. Cell Biol., 96, 999-1007.

Bradford,M.M. (1976) A rapid and sensitive method for the quantitation of microgram quantitues of protein utilizing the principle of protein dye binding. Anal. Biochem., 72, 248-254.

Cummings,R.D. and Kornfeld,S. (1982) Fractionation of asparaginelinked oligosaccharides by serial lectin affinity chromatography. J. Biol. Chem., 257, 11235-11240.

De Prijker,J., Vervoort,A. and De Bruyne,C.K. (1974) Purification and properties of $\alpha$-D-mannosidase from Mendicago sativa L. Eur. J. Biochem., 47, 561-566.

Elbein,A.D. (1988) Glycoprotein processing and glycoprotein processing inhibitors. Plant Physiol., 87, 291-295.

Elbein,A.D., Legler,G., Tlusty,A., McDowell,W. and Schwartz,R.T. (1984) The effect of deoxymannojirimycin on the processing of the influenza viral hemagglutinin. Arch. Biochem. Biophys., 235, 579-588.

Elbein,A.D., Tropea,J.E. and Kaushal,G.P. (1990) Kifunensine, a potent inhibitor of the glycoprotein processing mannosidase I. J. Biol. Chem., in press.

Faye,L., Greenwood,J.S., Herman,E.M., Sturm,A. and Chrispeels,M.J. 
(1988) Transport and posttranslational processing of the vacuolar enzyme $\alpha$-mannosidase in jack-bean cotyledons. Planta, 271-282.

Forsee,W.T. (1985) Characterization of microsomal and cytosolic $\alpha-1,2-$ mannosidases from mung bean hypocotyls. Arch. Biochem. Biophys., 242, 48-57.

Fuhrmann,U., Bause,E., Legler,G. and Ploegh,H. (1984) Novel mannosidase inhibitor blocking conversion of high-mannose to complex oligosaccharides. Nature, 307, 755-758.

Greve,L.C. and Ordin,L (1977) Isolation and purification of an $\alpha$ mannosidase from coleoptiles of Avena sattva. Plant Physiol., 60. $478-481$.

Harlow,E. and Lane,D. (1988) Anttbodies: a Laboratory Manual. Cold Spring Harbor Laboratory Press, Cold Spring Harbor, NY

Harpaz,N. and Schachter,H. (1980) Control of glycoprotein synthesis: bovine colostrum UDP- $N$-acetylglucosamine $\alpha$-D [IPS]-mannoside $\beta$ - 2 $\mathrm{N}$-acetylglucosaminyl transferase $\mathrm{I}$; separation from UDP- $N$-acetylglucosamine $\alpha$-D[IPS]-mannoside- $\beta$-2- $N$-acetylglucosaminyl transferase II. Partial purification and substrate specificity. J. Biol. Chem., 255 , 4884-4893.

Hohenschutz,L.D., Bell,E.A., Jewess,P.Y., Leworthy,D.D. and Pryce,R.Y. (1981) Castanospermine, a 1,6,7,8-tetrahydroxyoctahydroindolizidine alkaloid from seeds of Castanospermum australe. Phytochemistry, 20, $811-814$.

Hori,H. and Elbein,A.D. (1983) Processing of N-linked oligosaccharides in soybean cultured cells. Arch. Biochem Biophys., 220, 415-425.

Kang,M.S. and Elbein,A.D. (1983) Mechanism of inhibition of jackbean $\alpha$-mannosidase by swainsonine. Plant Physiol, 71, 551-554.

Kaushal,G.P., Szumilo,T., Pastuszak,I. and Elbein,A.D. (1990) Purification to homogeneity and properties ofmannosidase II from mung bean seedlings. Biochemistry, 29, 2168-2176.

Kornfeld,S (1990) Lysosomal enzyme targeting. Biochem. Soc. Trans, 18, $367-374$.

Kornfeld,R. and Kornfeld,S. (1985) Assembly of asparagine-linked oligosaccharides. Ann. Rev Biochem., 54, 631-634.

Laemml, U.K. (1970) Cleavage of structural proteins during the assembly of the head of bacteriophage $\mathrm{T}_{4}$. Nature, 227, 680-685.

Lauriere,M., Lauriere,C., Chrispeels,M.J., Johnson,K.D. and Sturm,A (1989) Characterization of a xylose-specific antiserum that reacts with the complex asparagine-linked glycans of extracellular and vacuolar glycoproteins. Plant Physiol., 90, 1182-1188.

McGee,C.M. and Murray,D.R. (1985) Localization of acid glycosidases in protein bodies of pea cotyledons. J. Plant Physiol., 120, $\mathrm{l}-8$

Molyneux,R J. and James,L.F. (I982) Loco intoxication' indolizıdine alkaloids of spotted locoweed (Astragalus lentiginosus). Science, 216. 190-191.

Neely,R.S. and Beevers,L. (1980) Glycosidases from cotyledons of Pisum sativum. J. Exp. Bot., 31, 299-312.

Nichimura,H. and Beevers,H. (1978) Hydrolases in vacuoles from castor bean endosperm. Plant Phystol., 62, 44-48.

Opheim,D.J. and Touster,O. (1978) Lysosomal $\alpha$-D-mannosidases of rat liver. Purification and comparison with the Golgi and cytosolic $\alpha-D$ mannosidases. $J$ Biol. Chem., 253, 1017-1023.

Oppenheimer,C.L. and Hill,R.L. (1981) Purification and characterization of a rabbit liver $\alpha-1,3$-mannoside $\beta$-1,2- $N$-acetylglucosaminyl transferase. J. Biol. Chem., 256, 799-804

Orr,M.D., Blakley,R.L. and Panagou,D. (1972). Discontinuous buffer systems for analytical and preparative electrophoresis of enzymes on acrylamide gels. Anal. Biochem., 45, 68-85.

Paus,E. (1977) $\alpha$-Mannosidase from Phaseolus vulgaris. Composition and structural properties. Eur. J. Biochem.. 73, 155-161.

Saita,M., Ikenaka,T. and Matushima,Y. (1971) Isolation and characterization of $\alpha$-D-mannosidase from soybean. J. Biochem., 70, 827-833.

Szumilo,T. and Elbein,A.D. (1985) A simple and reliable assay for glycoprotein processing. Anal. Biochem., 151, 32-40.

Szumilo,T., Kaushal,G.P., Hori,H and Elbein,A.D. (1986a) Purification and properties of a glycoprotein processing $\alpha$-mannosidase from mung bean seedlings. Plant Physiol., 81, 383-389.

Szumilo,T., Kaushal,G.P. and Elbein,A.D. (1986b) Demonstration of GicNAc transferase I in plants. Biochem. Biophys. Res. Commun., 134, 1395-1403.

Towbin,H.. Staehelin,T. and Gordon,J. (1979) Electrophoretic transfer of proteins from polyacrylamide gels to nitrocellulose sheets. Procedure and some applications. Proc. Nall. Acad. Sci. USA, 76, 4350-4354.

Tropea,J.E., Kaushal,G.P., Pastuszak,I.. Mitchell,M.. Aoyagi,T. and Elbein.A.D. (1990) Mannostatin A, a new glycoprotein processing inhibitor. Biochemistry, in press.
Tulsiani,D P.R., Hubbard,S.C., Robbins,P.W. and Touster,O. (1982a) $\alpha$ $D$-Mannosidases of rat liver Golgi membranes: Mannosidase II is

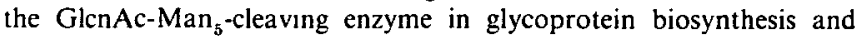
mannosidase $1 \mathrm{~A}$ and $1 \mathrm{~B}$ are the enzymes converting $\mathrm{Man}_{9}$ precursors to Man $_{5}$ intermediates. J. Biol. Chem., 257, 3660-3667.

Tulsiani,D.P.R., Harris,T.M. and Touster,O. (1982b) Swainsonine inhibits the biosynthesis of complex glycoproteins by inhibition of Golgi mannosidase II. J. Bıol. Chem., 257, 7936-7939.

Van der Wilden,W. and Chrispeels,M.J. (1983) Characterization of the isozymes of $\alpha$-mannosidase located in the cell wall, protein bodies and endoplasmic reticulum of Phaseolus vulgaris cotyledons. Plant Physiol, 71, 82-87

Vitale,A. and Chrispeels,M.J. (1984)Transient $N$-acetylglucosamine in the bıosynthesis of phytohemagglutinin: attachment in the Golgi apparatus and removal in proteın bodies. J. Cell. Bıol., 99, 133-140.

Received on July 20, 1990; accepted on August 7, 1990 